\title{
Amperometric Enzyme-Free Glucose Sensor Based on Electrodeposition of Au Particles on Polyaniline Film Modified Pt Electrode
}

\author{
Shveta Malhotra, ${ }^{1,2}$ Yijun Tang ${ }^{1, *}$ and Pradeep K. Varshney ${ }^{2}$ \\ ${ }^{1}$ Department of Chemistry, University of Wisconsin Oshkosh, USA, 54901 \\ ${ }^{2}$ Department of Chemistry, Faculty of Engineering \& Technology, Manav Rachna International Institute \\ of Research \& Studies (a deemed-to-be-University), Faridabad, India, 121004 \\ *Corresponding author: E-mail: tangy@uwosh.edu \\ Tel: +1 (920) 424-7097
}

Received: 29-03-2018

\begin{abstract}
An amperometric non-enzymatic glucose sensor of high sensitivity was developed by modification of Pt electrode with electrodeposition of Au particles on polyaniline film. The Au particles were deposited under optimum growth conditions for maximum dispersion on polymer film to achieve highly sensitive glucose sensor. The characterization of the electrode and the analytical parameters were evaluated using chronoamperometry and cyclic voltammetry techniques. The sensor showed wide linear range from $0.01-8 \mathrm{mM}$ along with swift response time of less than $5 \mathrm{~s}$. Moreover, a high sensitivity of 113.6 $\mu \mathrm{A} \mathrm{mM} \mathrm{mm}^{-1} \mathrm{~cm}^{-2}$ is obtained along with low detection limits of $0.5 \mu \mathrm{M}$. The sensor also showed high stability, reproducibility, and repeatability. Furthermore, the sensor has shown high selectivity towards glucose exclusively in the presence of interferents such as sucrose, uric acid, and ascorbic acid. The practical applicability of the proposed sensor was confirmed from successful analysis of glucose in different juice samples and these results were comparable to the commercial glucose meter. Thus, our sensor stands promising non-enzymatic sensor for routine analysis of glucose.
\end{abstract}

Keywords: Non-enzymatic, Glucose sensor, Polyaniline, Cyclic Voltammetry, Chronoamperometry

\section{Introduction}

The detection of glucose in not limited to clinical diagnosis but also used in the other fields such as pharmaceutical, food, and biotechnology. ${ }^{1}$ The research in the fabrication of glucose sensors is tremendous due to the need of highly stable and sensitive sensors. ${ }^{2}$ The amperometric glucose sensors are either enzymatic or non-enzymatic. ${ }^{3,4}$ The development of former sensors took a leap after development of first enzyme-based sensor in 1962. In spite of the tremendous research in the field of enzyme-based sensors still the need remains for development of highly stable sensors. ${ }^{5}$ One of the reasons is that enzyme loses their activity due to change in the environmental conditions and thereof these sensors are not stable for long term use. While in the case of non-enzymatic sensors, direct electron transfer for oxidation of glucose takes place without the activity of enzymes. ${ }^{6}$ The catalytic behavior in these sensors has been attained by the presence of metals or alloys.
Researchers are focusing on development of an ideal glucose sensor that is highly stable, sensitive, reproducible and has a fast response. ${ }^{7}$ All these analytical parameters can be attained in a single electrode by modification of the existing electrodes with conducting polymer-metal nanoparticles composites. ${ }^{8}$ In such composites, the role of conducting polymer is to provide mechanical stability and high conductivity while the dispersion of metal nanoparticles is responsible for the catalytic action of the sensor. Conducting polymers such as polyaniline (PANI), poly(o-phenylenediamine) (PoPD), polythiophenes, poly(3, 4-ethylenedioxythiophene) (PEDOT), polyvinylferrocenium, and polypyrrole (PPY) have been researched in the fabrication of ideal sensors. ${ }^{9-15}$ These polymers make available active sites for the dispersion of metal nanoparticles. The contribution of PANI is the greatest as it has a wide range of conductance (over 11 orders), excellent polymerization yield, and is stable to environmental conditions. ${ }^{16}$ Three oxidizable forms of PANI exist in an 
acid solution. These are emeraldine salt (ES), pernigraniline salt (PS), and leucomeraldine salt (LS). The ES-PANI can either be reduced to PS-PANI or oxidized to LS-PANI. The ES-PANI is the only conductive form of PANI and hence used in the development of sensors. ${ }^{17}$

The surface area of the electrode is increased with maximum dispersion of metal particles on the polymer film that contributes towards the increased electrocatalytic behavior. The immobilization of metal particles on the polymer matrix is greatly affected by certain factors such as analyte concentration, electrodeposition time, temperature, and method of preparation. ${ }^{18}$ Different noble metals are being researched for development of glucose sensors such as $\mathrm{Pd}, \mathrm{Pt}$, and $\mathrm{Au}$. The gold particles were our source of interest in this study due to its better electrocatalytic behavior and maximum dispersion on polymer matrix. Moreover, $\mathrm{Au}$ particles have advanced biocompatibility, anti-poising characteristic and wide range of oxidation potential. ${ }^{8}$

Herein, we report the development of amperometric non-enzymatic sensor with electrodeposition of Au particles on PANI film modified Pt electrode for detection of glucose. The Au particles were electrodeposited from $\mathrm{KAuCl}_{4}$ solution. The optimum concentration of the analyte and deposition time was evaluated for maximum dispersion of Au particles. The current response of as-prepared sensor $(\mathrm{Au} / \mathrm{PANI} / \mathrm{Pt})$ was studied under different concentrations of glucose using CV technique. The analytical parameters such as sensitivity, selectivity, limit of detection, linear range of concentration, and response time was also studied using chronoamperometry technique. The sensor was evaluated for its practical applicability in analysis of glucose in juice samples and these results were compared with commercial glucose meter.

\section{Experimental}

\section{1. Chemicals \& Apparatus}

Potassium chloride (KCl, Fisher Scientific, $100.2 \%$ ), potassium tetrachloroaurate(III) $\left(\mathrm{KAuCl}_{4}\right.$, Aldrich, 98\%), aniline $\left(\mathrm{C}_{6} \mathrm{H}_{5} \mathrm{NH}_{2}\right.$, Oakwood Chemicals, $\left.\geq 99.0 \%\right)$, sodium hydroxide $(\mathrm{NaOH})$ (Fisher Scientific, 99.4\%), uric acid (UA, Nutritional Biochemicals Corporation), ascorbic acid (AA, Acros Organics), sucrose (Aldrich), D-glucose (Macron Fine Chemicals). All the chemicals were used as received. The $\mathrm{KAuCl}_{4}$ solution was prepared in $0.01 \mathrm{M} \mathrm{KCl}$. All the water-based solutions were prepared in deionized water and glucose solutions in $0.1 \mathrm{M} \mathrm{NaOH}$. In all the experiments, 3-electrode system was used with modified Pt electrode (working electrode), Pt wire electrode (counter electrode), and calomel electrode (SCE) (reference electrode). The CV and CA techniques were performed using electrochemical analyzer (CHI750C Electrochemical Workstation), purchased from $\mathrm{CH}$ Instruments, Inc., USA. Scanning electron microscopy (SEM) was used to study the morphological properties of the sensor using Hitachi Scanning Electron Microscope SN-
2460. When not in use, the working modified Pt electrode was stored at room temperature. Also, all the experiments in this report were carried out at room temperature.

\section{2. Preparation of Au/PANI/Pt Electrode}

The bare Pt electrode was mirror polished with the alumina slurries (in order: 0.1, 0.3 and $0.05 \mu \mathrm{m}$ ) then rinsed and ultrasonicated in deionized water for $10 \mathrm{~min}$. The polished electrode was dipped in $1 \mathrm{M} \mathrm{H}_{2} \mathrm{SO}_{4}$ and potential sweep applied between $-0.2 \mathrm{~V}$ and $+0.7 \mathrm{~V}$ to obtain clean Pt electrode (scan rate: $50 \mathrm{mVs}^{-1}$ ). The shiny cleaned electrode was dried in air for the electrodeposition of PANI film.

The electrodeposition of PANI film on the Pt electrode was done from $50 \mathrm{mM}$ aniline in $1 \mathrm{M} \mathrm{HCl}$ solution by sweeping potential in the range of $-0.2 \mathrm{~V}$ to $+0.1 \mathrm{~V}$ for 20 cycles at $50 \mathrm{mVs}^{-1}$. The green color coating of PANI film on Pt electrode was observed. Then the electrode was rinsed with deionized water and over-oxidation of PANI film was done by applying potential of $+0.1 \mathrm{~V}$ for $300 \mathrm{~s}$ in $0.1 \mathrm{M} \mathrm{NaOH} .{ }^{19}$ This electrode was labeled as PANI/Pt.

For the dispersion of the Au particles on PANI film, the as-prepared PANI/Pt electrode was immersed in $\mathrm{KAu}$ $\mathrm{Cl}_{4}$ solution for $3600 \mathrm{~s}$ then the Au particles were electrodeposited in potentiostatic mode for $600 \mathrm{~s}$ at a potential of $-0.5 \mathrm{~V}^{20}$ Then the electrode was rinsed with deionized water and dried in air. This electrode was labeled as $\mathrm{Au} /$ PANI/Pt. The entire scheme for preparation of the proposed sensor is shown in Scheme 1.

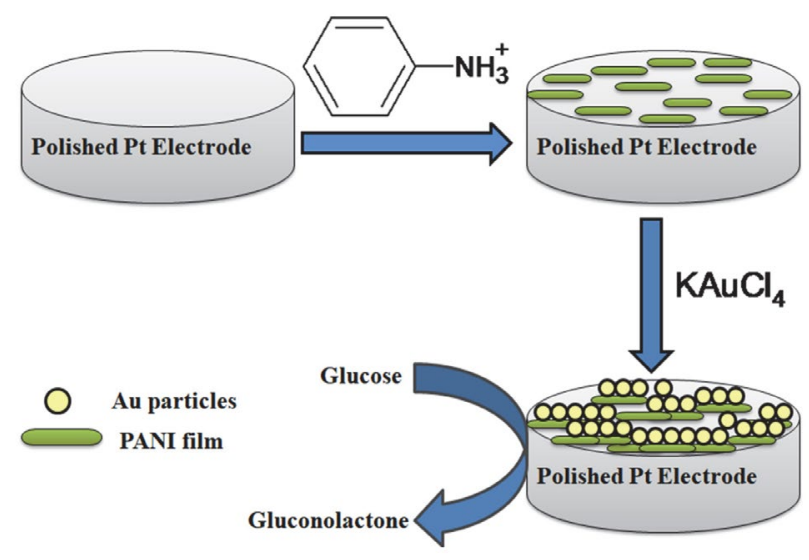

Scheme 1. Preparation of Au particles immobilized on PANI film modified Pt electrode.

\section{Results and Discussions}

\section{1. Characterization of Au/PANI/Pt Electrode}

SEM images of PANI/Pt and Au/PANI/Pt modified electrodes were obtained to study the surface morphology 


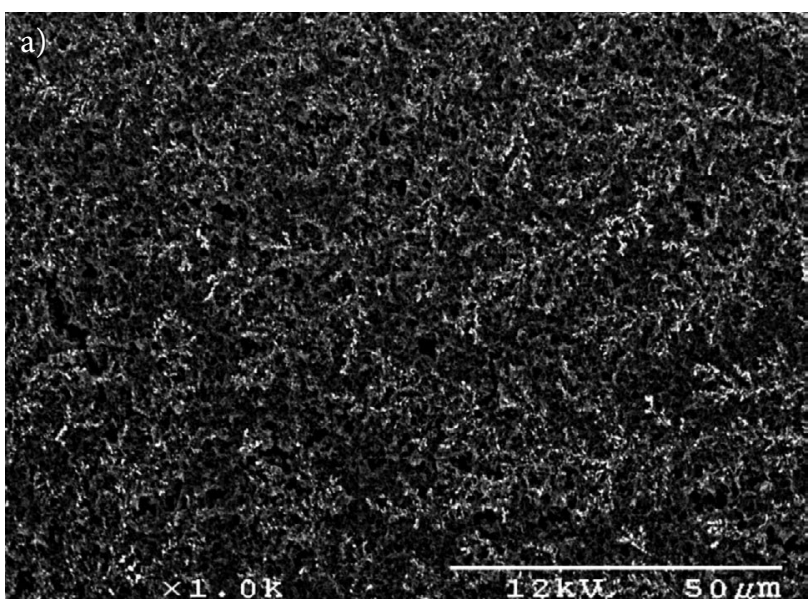

Figure 1. SEM images of (a) PANI/Pt (b) Au/PANI/Pt electrodes.

of the sensor. A network of PANI film is observed on PANI/Pt electrode (Fig. 1a) that provides appropriate surface area for the immobilization of the Au particles. Fig. $1 \mathrm{~b}$ indicates that Au particles are distributed all over the surface of the PANI film with an average size of $130 \mathrm{~nm}$.

The polyaniline film was electrodeposited on Pt electrode through in-situ electro polymerization of aniline done using $\mathrm{CV}$ technique at scan rate of $50 \mathrm{mVs}^{-1}$. As shown in Fig. 2a, the current increases with the increase in number of cycles and reaches maximum at 20 scan cycles. Precisely, with cycles higher than 20 the current becomes constant and a decrease in current response is also observed (Fig. 2b). Thus, we carried out the polymerization of aniline at 20 scan cycles.

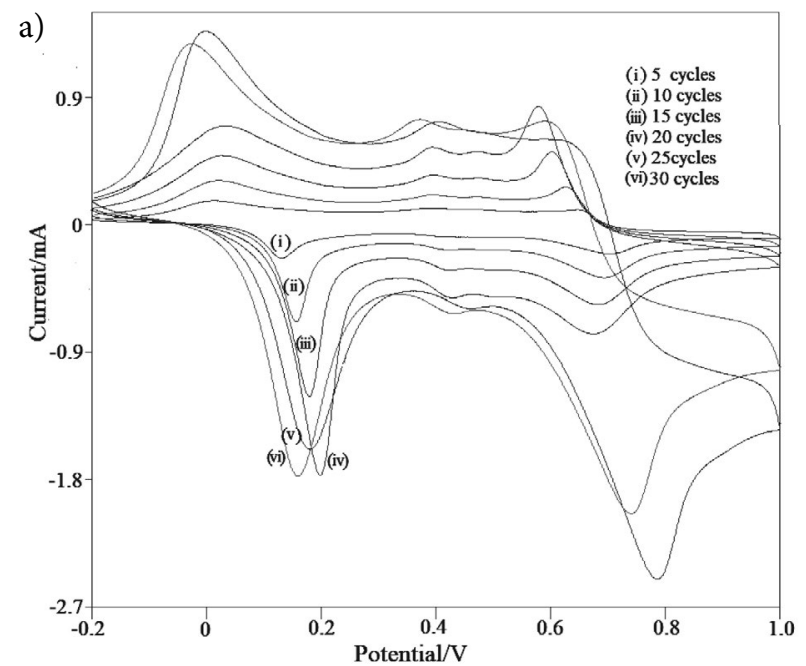

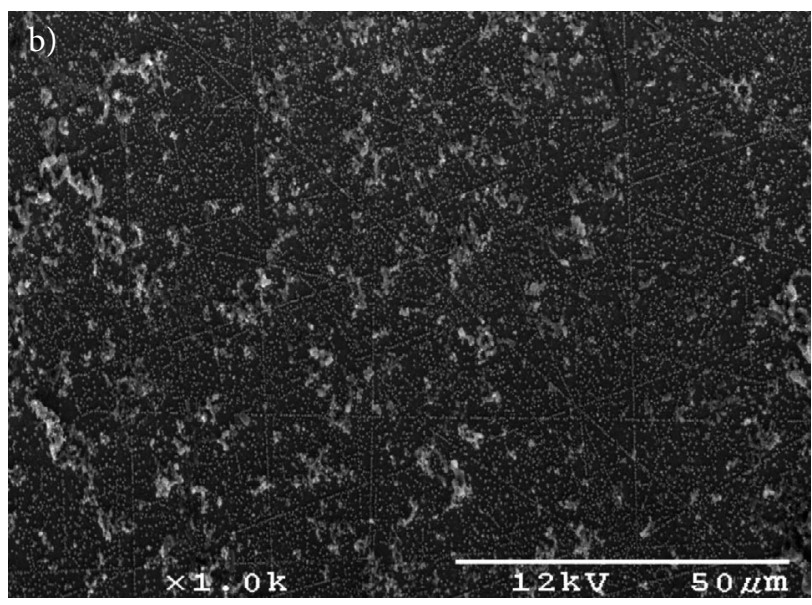

peak at $+0.81 \mathrm{~V}$ is attributed to the oxidation from the emeraldine (ES) $\rightarrow$ pernigraniline (PS) oxidation state. ${ }^{19}$ The increase in current with increase in subsequent number of cycles indicates that the thickness of the polymer film increases with each cycle. After the complete polymerization, the surface of the modified electrode is coated with green color indicating the formation of conductive ESPANI. The deposition of Au particles on PANI matrix is performed based on selection of optimum growth conditions for better performance of our sensor.

A typical voltammogram for $\mathrm{Au} / \mathrm{PANI}$ composite is shown in Fig. 3b. The peak at $+0.22 \mathrm{~V}$ is to some extent restrained in presence of $\mathrm{Au}(0)$ as compared to PANI film (Fig. 3a). This can be due to the ejection of protons. ${ }^{21}$ The

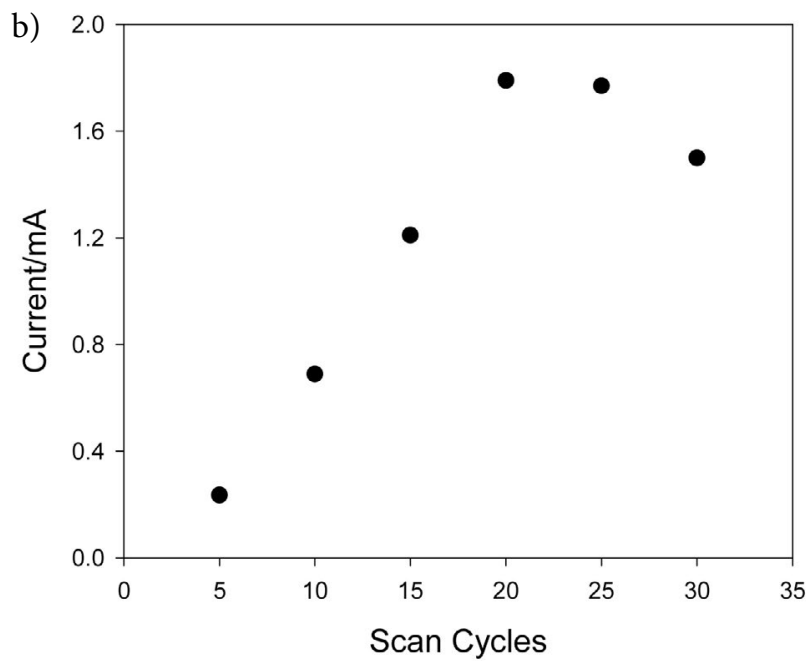

Figure 2. (a) Cyclic voltammogram of polymerization of aniline on Pt electrode at (i) 5 cycles, (ii) 10 cycles, (iii) 15 cycles, (iv) 20 cycles, (v) 25 cycles (vi) 30 cycles. (b) Plot of anodic peak current with number of scan cycles for polymerization of aniline.

The voltammogram obtained (Fig. 3a) shows well defined two redox couples at potential $+0.24 \mathrm{~V}$ and +0.81 $\mathrm{V}$ confirming the formation of PANI film. The peak at $+0.20 \mathrm{~V}$ is ascribed to the transition from the leucoemeraldine (LS) $\rightarrow$ emeraldine (ES) oxidation state while the peak at $+0.48 \mathrm{~V}$ corresponds to the intermediate complex $\left[\mathrm{PANI}^{*} \mathrm{AuCl}_{4}^{-}\right]$formed during the reaction between anilinium ion and $\mathrm{KAuCl}_{4}$ (Eq. 1). The reduction of the complex at this potential yields $\mathrm{Au}(0)$. This intermediate complex is not affected by the change of composition of the 
electrolyte. The peak at $+0.76 \mathrm{~V}$ is attributed to absorption of anions by the polymer. ${ }^{22}$ The conductivity of the PANI/ Au composite sensor is maintained due to the presence of oxidized and reduced species in equal number as well as high levels of proton doping. ${ }^{23}$
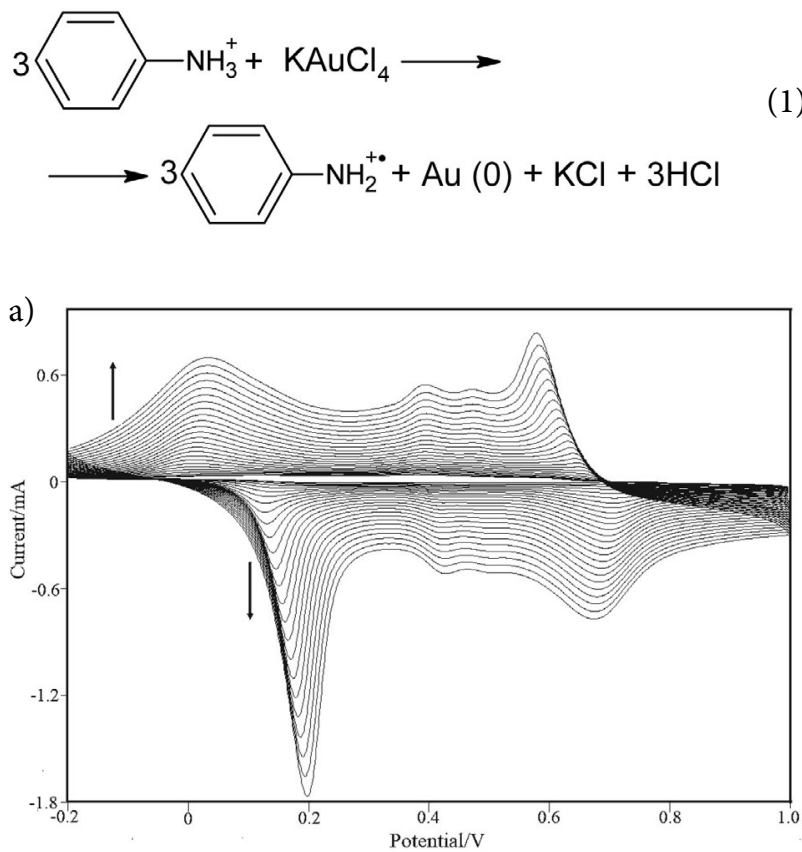

b)

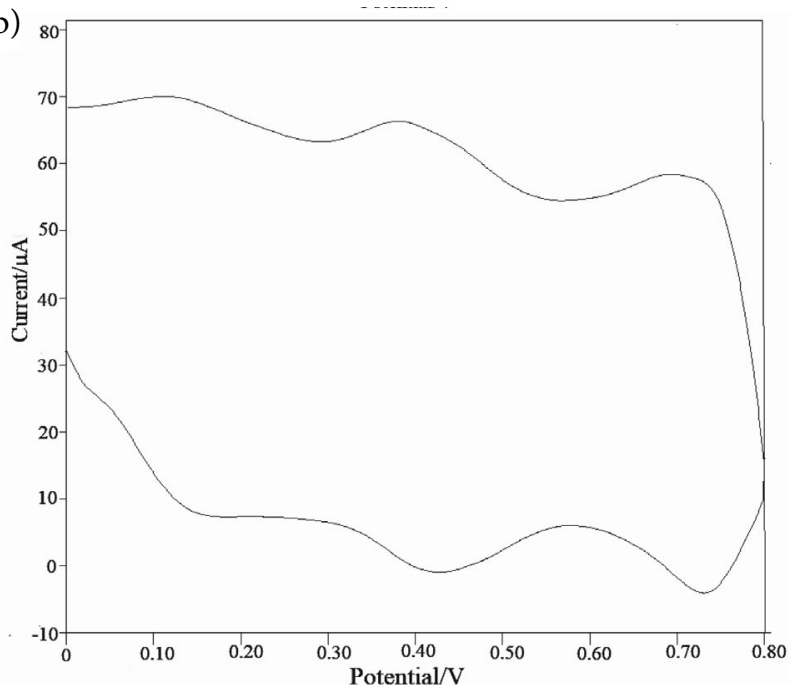

Figure 3. Cyclic voltammogram of (a) electropolymerization of PANI film on Pt electrode in $50 \mathrm{mM}$ aniline in $1 \mathrm{M} \mathrm{HCl}$ (b) Au deposited on PANI film modified Pt electrode in $1 \mathrm{M} \mathrm{HCl}$. Scan rate: $50 \mathrm{mVs}^{-1}$.

\section{2. Optimization of Conditions}

\section{2. 1. Growth of Au Particles}

It is an essential criterion to select the optimum concentration of $\mathrm{KAuCl}_{4}$ solution for maximum dispersion of
Au particles on polymer. To achieve this, we prepared different concentrations of $\mathrm{KAuCl}_{4}$ solution $(0.25-1.5 \mathrm{mM})$ in $0.01 \mathrm{M} \mathrm{KCl}$ and recorded the response current towards oxidation of $1 \mathrm{mM}$ glucose solution. Fig. 4a displays the variation of anodic peak current with different $\mathrm{KAuCl}_{4}$ concentrations. As observed, the anodic peak current increases up to $0.5 \mathrm{mM} \mathrm{KAuCl}_{4}$ after which the catalytic action of $\mathrm{Au}$ decreases and peak current gradually falls. This can be attributed to the fact that concentration $>0.5 \mathrm{mM}$ results in aggregation of $\mathrm{Au}$ particles that causes decrease in electrocatalytic performance of the electrode. Thus, we selected $0.5 \mathrm{mM} \mathrm{KAuCl}_{4}$ concentration for deposition of Au particles.

Furthermore, deposition time required for Au particles was also considered during the fabrication process of the sensor. The Au particles were allowed to deposit on the PANI/Pt electrode for different time periods (1200-4800 s) and the current was observed towards oxidation of 1 $\mathrm{mM}$ glucose. As evident from Fig. $4 \mathrm{~b}$, the maximum anodic peak current is observed at $3600 \mathrm{~s}$ and afterwards it decreases. Hence, the optimum growth time for Au particles was selected as $3600 \mathrm{~s}$.
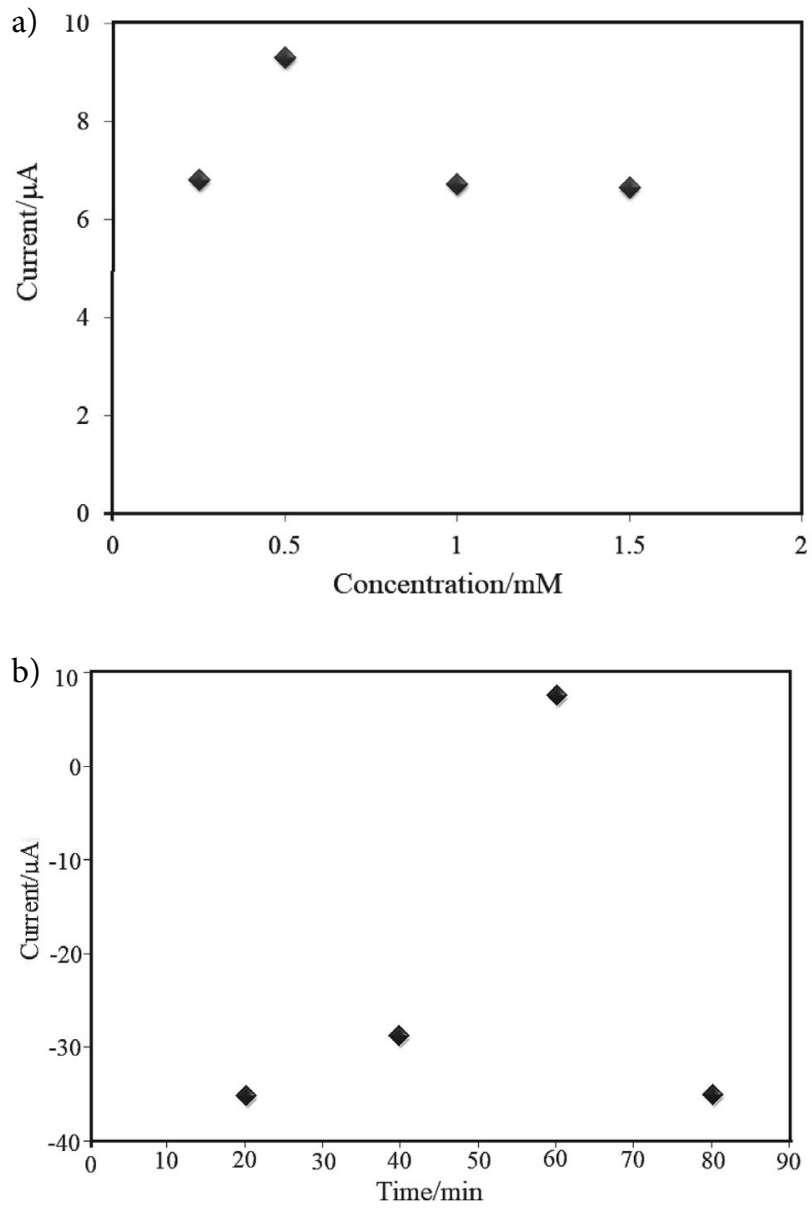

Figure 4. Variation of anodic peak current towards oxidation of 1 $\mathrm{mM}$ glucose in $0.1 \mathrm{M} \mathrm{NaOH}$ with different (a) $\mathrm{KAuCl}_{4}$ concentrations (b) Deposition time. 


\section{2. 2. Optimum $\mathrm{NaOH}$ Concentration}

The mechanism behind the electro-oxidation process of glucose to gluconolactone in the presence of $\mathrm{Au}$ particles is understood with the formation of active Au hydroxides $\left(\mathrm{AuOH}_{\mathrm{ads}}\right)$. The presence of $\mathrm{OH}^{-}$directly influences the formation of $\mathrm{AuOH}$ that is essential for the oxidation process of glucose on surface of Au. The active $\mathrm{AuOH}_{\mathrm{ads}}$ acts as catalyst and initiates the process of adsorption of dehydrogenated intermediates during oxidation process of glucose. The formation of $\mathrm{AuOH}_{\mathrm{ads}}$ on $\mathrm{Au}$ occurs readily in alkaline medium rather than neutral or acidic medium. ${ }^{24,25}$ Thus we prefer to study the performance of our sensor in strong alkaline medium.

The protons generated from dehydrogenation intermediate steps of glucose are neutralized by the $\mathrm{OH}^{-}$. This is greatly affected by increasing the alkalinity of the solution. Hence, we also evaluated the performance of the sensor in different concentrations of $\mathrm{NaOH}(0.01 \mathrm{M}-0.2 \mathrm{M})$. As evident from Fig. 5, the maximum current is observed for oxidation of glucose in $0.1 \mathrm{M} \mathrm{NaOH}$ solution. The increase in anodic current response with increasing concentration of $\mathrm{NaOH}$ might be due to the rapid formation of $\mathrm{AuOH}_{\mathrm{ads}}$ that catalyses the glucose oxidation. While at higher $\mathrm{NaOH}$ concentrations $\mathrm{Au}$ is transformed to water-soluble ion $\mathrm{HAuO}_{3}{ }^{-24,26}$

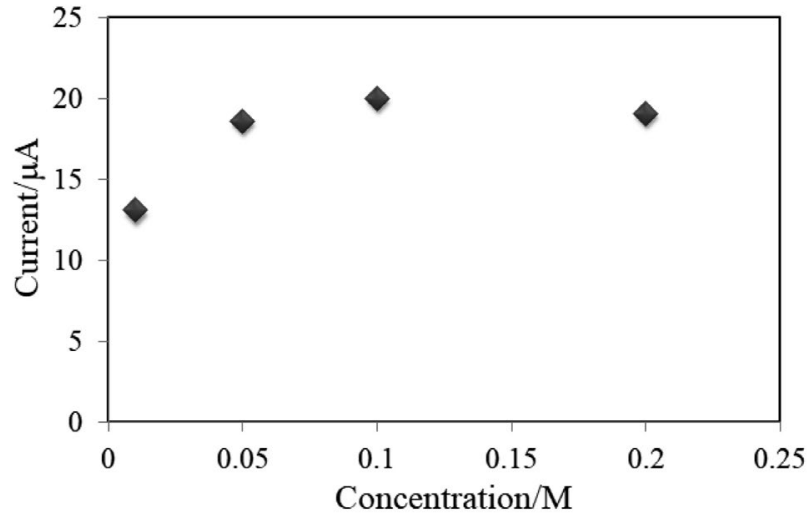

Figure 5. Variation of anodic peak current with $10 \mathrm{mM}$ glucose in different concentrations of $\mathrm{NaOH}$.

\subsection{Electrocatalytic Behavior Towards Glucose}

Fig. 6a shows the oxidation of $1 \mathrm{mM}$ glucose in $0.1 \mathrm{M}$ $\mathrm{NaOH}$ with bare Pt, PANI/Pt and Au/PANI/Pt electrodes. As observed, no obvious peak of glucose oxidation is observed with bare $\mathrm{Pt}$ and PANI/Pt electrode while the prominent oxidation peak is observed in case of Au/PANI/ Pt electrode. The presence of AuNPs on the surface of $\mathrm{Au} /$ PANI/Pt electrode leads to formation of $\mathrm{AuOH}_{\text {ads }}$ which catalyzes the oxidation of glucose to gluconolactone. Thus, a sharp increase in the anodic current response towards glucose is observed with $\mathrm{Au} / \mathrm{PANI} / \mathrm{Pt}$ electrode. The voltammograms in Fig. 6a are observed to cross each other due to the fact that in Au/PANI/Pt curve the presence of AuNPs enhances the anodic peak current for glucose oxidation. The AuNPs are dispersed all over the surface of the PANI film and hence promote electron transfer for redox process. Thus, Au/PANI/Pt curve crosses bare $\mathrm{Pt}$ and PANI/Pt curves where the anodic peak current is negligible or low. The prominent current response with $\mathrm{Au} /$ PANI/Pt electrode in comparison to the current response of bare Pt and PANI/Pt electrodes enables us to detect glucose. This confirms that the oxidation of glucose is initiated by the presence of Au particles in Au/PANI/Pt sensor. Thus, the oxidation of glucose is significantly improved because of the electrocatalytic behavior of Au particles.

Furthermore, Fig. $6 \mathrm{~b}$ represents the current response of $\mathrm{Au} / \mathrm{PANI} / \mathrm{Pt}$ electrode in the absence and presence of 16 $\mathrm{mM}$ glucose. A broader anodic peak for the oxidation of
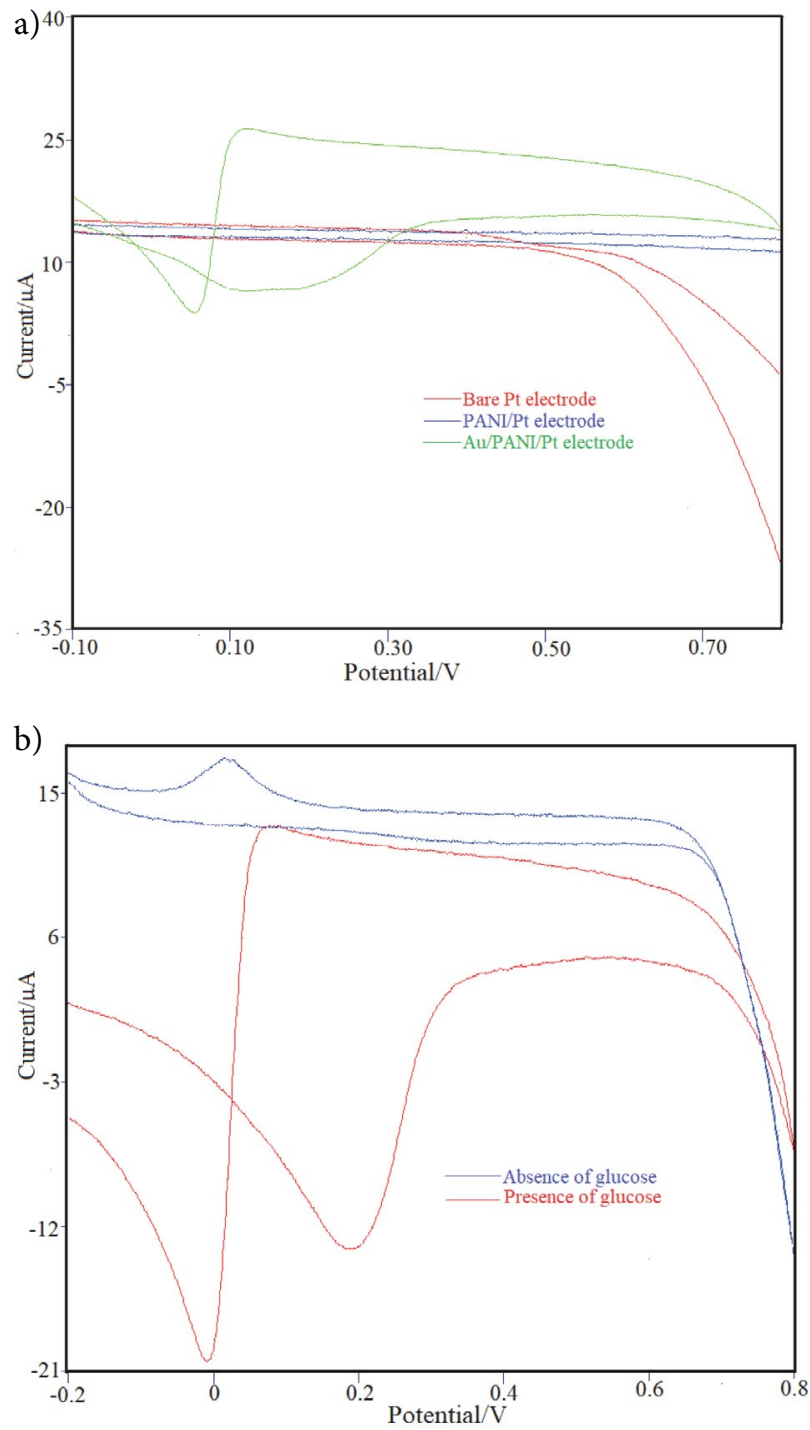

Figure 6. (a) CVs of bare Pt electrode, PANI/Pt electrode, and Au/ PANI/Pt electrode towards oxidation of $1 \mathrm{mM}$ glucose in $0.1 \mathrm{M}$ $\mathrm{NaOH}$. (b) Current response of $\mathrm{Au} / \mathrm{PANI} / \mathrm{Pt}$ sensor in absence and presence of $16 \mathrm{mM}$ glucose in $0.1 \mathrm{M} \mathrm{NaOH}$ (scan rate: $50 \mathrm{mVs}^{-1}$ ). 
glucose can be observed in presence of glucose while no obvious peak is observed in blank solution. This further confirms that our sensor shows prominent oxidation of glucose.

\section{4. Effect of Scan Rate}

The Au/PANI/Pt sensor was evaluated for the oxidation of glucose at different scan rates in CV. As observed from Fig. 7a, the current response increases with increase in scan rate towards oxidation of $1 \mathrm{mM}$ glucose. A linear graph is obtained for the plot of anodic peak current $\left(\mathrm{I}_{\mathrm{p}}\right)$ vs scan rate $(v)$ with linear regression coefficient, $R^{2}=0.9932$ (Fig. 7b). This confirms that process of glucose oxidation is a surface controlled phenomenon with adsorption of glucose on surface of electrode. ${ }^{27}$

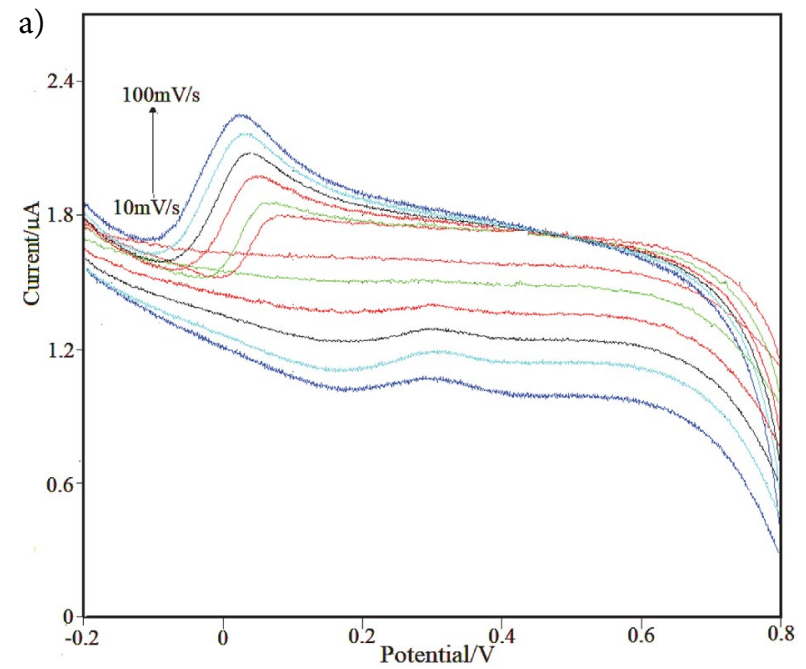

technique. First, the applied potential was selected where the substantial current is observed due to oxidation of glucose. We studied the effect of applied potential using Hydrodynamic Modulation Voltammetry (HMV) technique. Fig. 8 shows the voltammogram obtained for oxidation of $10 \mathrm{mM}$ glucose. The current gradually increases to maximum at potential $+0.067 \mathrm{~V}$ after which it gradually decreases. Hence, all the chronoamperometric experiments of Au/PANI/Pt were performed at $+0.067 \mathrm{~V}$.

For chronoamperometric measurement various concentrations of glucose were successively added to $0.1 \mathrm{M}$ $\mathrm{NaOH}$ at an interval of $50 \mathrm{~s}$. The solution was constantly stirred during the run of the experiment. Fig. 9a shows the chronoamperometric current response obtained for successive additions of glucose. As evident from figure, the

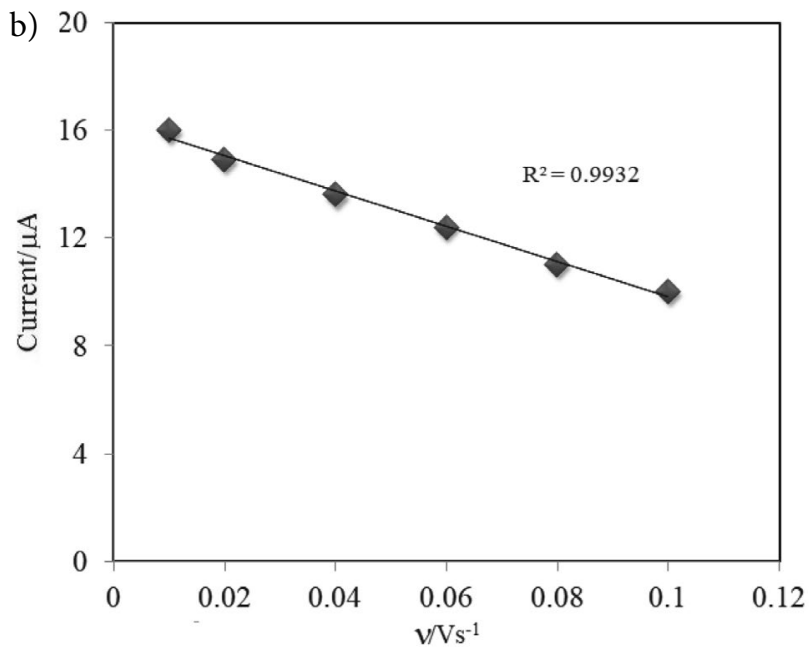

Figure 7. (a) CVs of Au/PANI/Pt electrode studied at various scan rates: 10, 20, 40, 60, 80, and $100 \mathrm{mVs}^{-1}$ with $1 \mathrm{mM}$ glucose in $0.1 \mathrm{M} \mathrm{NaOH}$. (b) Plot of $I_{p}$ vs. scan rate.

\section{5. Evaluation of Analytical Parameters}

\subsubsection{Chronoamperometric Response of $\mathrm{Au} /$ PANI/Pt Sensor}

After optimizing the conditions for the fabrication of sensor, its analytical parameters were evaluated using CA

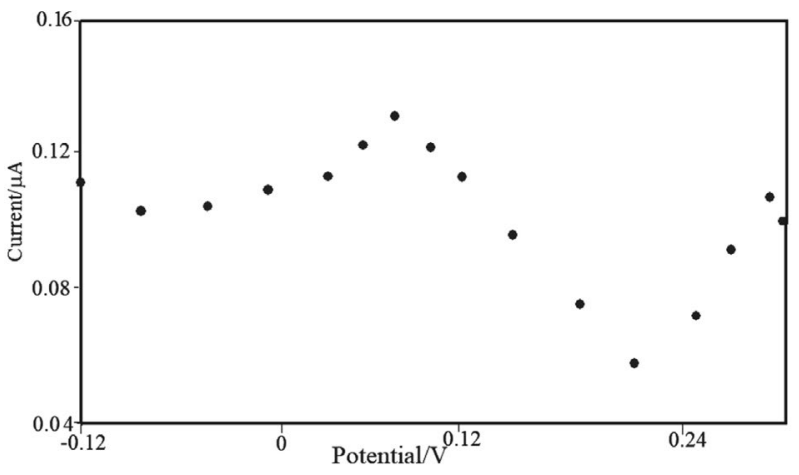

Figure 8. Variation of applied potential with Au/PANI/Pt electrode towards $10 \mathrm{mM}$ glucose in $0.1 \mathrm{M} \mathrm{NaOH}$. response current increases with increasing concentrations of glucose. As observed from the insert of the Fig. 9a, the sensor achieved $95 \%$ of the steady-state current response in less than $5 \mathrm{~s}$. The calibration plot observed for the wide glucose concentrations from $0.01 \mathrm{mM}-8 \mathrm{mM}$ is linear with regression coefficient, $\mathrm{R}^{2}=0.9946$ (Fig. 9b). The sensitivity of the sensor is calculated as $113.6 \mu \mathrm{A} \mathrm{mM}^{-1} \mathrm{~cm}^{-2}$ from Eq. (2)

$$
\begin{aligned}
& \text { Sensitivity }= \\
& =\frac{\text { Slope of the Chronoamperometric Calibration Curve }}{\text { Active Surface Area }}
\end{aligned}
$$

The active surface area is calculated from RandlesSevcik Equation (Eq. 3) as the method described by Chaiyo et $\mathrm{al}^{28}$,

$$
\mathrm{I}_{\mathrm{p}}=268600 \mathrm{n}^{(3 / 2)} \mathrm{A} \mathrm{D}^{(1 / 2)} \mathrm{C} v^{(1 / 2)}
$$

where, $I_{p}$ - peak current $(A), n$ - number of electron transfer, D - diffusion coefficient $\left(\mathrm{cm}^{2} / \mathrm{s}\right), \mathrm{C}$ - bulk concentra- 

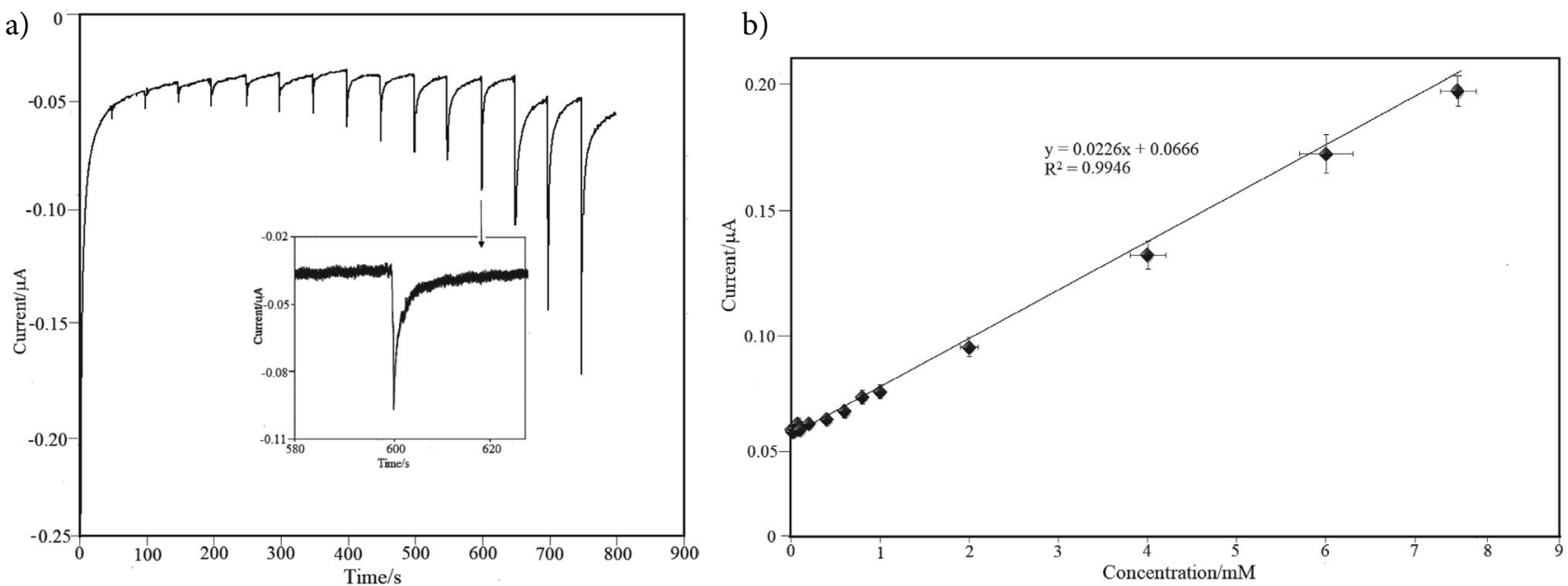

Figure 9. (a) Chronoamperometric response of Au/PANI/Pt modified electrode in $0.1 \mathrm{M} \mathrm{NaOH}$ (applied potential: $+0.067 \mathrm{~V}$ ). Insert shows the enlarged image of response time at $600 \mathrm{~s}$. (b) Calibration plot between current and glucose concentrations.

tion $\left(\mathrm{mol} / \mathrm{cm}^{3}\right), \mathrm{A}$ - surface area of the electrode $\left(\mathrm{cm}^{2}\right)$, and $v$ - scan rate $(\mathrm{V} / \mathrm{s}) .{ }^{26}$ Briefly, the voltammograms of the modified electrode were recorded in $0.01 \mathrm{mM}$ of potassium ferrocyanide $\left[\mathrm{K}_{4} \mathrm{Fe}(\mathrm{CN})_{6}\right]$ redox couple at different scan rates $(10,20,40,60,80$ and $100 \mathrm{~V} / \mathrm{s})$. The slope obtained from linear calibration curve of $\mathrm{I}_{\mathrm{p}} \mathrm{vs} \mathrm{v}^{1 / 2}$ is substituted in Eq. (3). From this, the active surface area of the modified electrode is calculated as $0.000278 \mathrm{~cm}^{2}$. This value is very low and seems to be contradictory to the actual geometrical surface area of the electrode. However, it should be observed here that that concentration of $\mathrm{Au}$ and PANI used in this experiment is very low and have resulted in smaller active surface area available for oxidation. However, even with such small area we were able to get high sensitivity for our sensor.
The low detection limits calculated for our sensor is $0.5 \mu \mathrm{M}(\mathrm{S} / \mathrm{N}=3)$ with the help of Eq. (4)

$$
\mathrm{LOD}=\frac{3 \sigma}{\mathrm{S}}
$$

Where, $\sigma$ - standard deviation of blank solution (10 readings) and $s$ - slope of the calibration curve.

The performance parameters of our sensor are comparable to other $\mathrm{Au}$ particles based enzyme-free glucose sensors reported recently, listed in Table 1.

\section{5. 2 Selectivity \& Stability}

Many interfering species such as AA, UA, and sucrose have activities similar to glucose and thus inter-

Table 1. Comparison of performance parameters of Au/PANI/Pt sensor to recently reported non-enzymatic glucose sensors based on Au particles

\begin{tabular}{|c|c|c|c|c|}
\hline Electrode & LOD & Linear Range & $\begin{array}{c}\text { Sensitivity } \\
\left(\mu \mathrm{A} \mathbf{m M}^{-1} \mathbf{c m}^{-2}\right)\end{array}$ & References \\
\hline AuNPs-MWCNTs-Chitosan/Au & $0.5 \mu \mathrm{M}$ & $0.001 \mathrm{mM}-1.0 \mathrm{mM}$ & 27.7 & {$[24]$} \\
\hline AuNP/GONR/Carbon sheet & $0.5 \mu \mathrm{M}$ & $0.5 \mu \mathrm{M}-10 \mathrm{mM}$ & 57.1 & [29] \\
\hline AuNPs/GC & $0.05 \mathrm{mM}$ & $0.1 \mathrm{mM}-25 \mathrm{mM}$ & 87.5 & {$[30]$} \\
\hline Pd-Au cluster/GC & $50 \mu \mathrm{M}$ & $0.1 \mathrm{mM}-30 \mathrm{mM}$ & 75.3 & {$[31]$} \\
\hline GNPs/PANI/GCE & $0.1 \mathrm{mM}$ & $0.3 \mathrm{mM}-10 \mathrm{mM}$ & NA & {$[32]$} \\
\hline AuNP/GPE & $12 \mu \mathrm{M}$ & $0.05 \mathrm{mM}-5.0 \mathrm{mM}$ & 52.61 & {$[33]$} \\
\hline $\mathrm{Au}-\mathrm{NTAs} / \mathrm{GCE}$ & $2.1 \mu \mathrm{M}$ & $5 \mu \mathrm{M}-16.4 \mathrm{mM}$ & 44.2 & {$[34]$} \\
\hline AuNPs/SPCE & $200 \mu \mathrm{M}$ & $0.5 \mathrm{mM}-8.5 \mathrm{mM}$ & $9.12^{*}$ & {$[35]$} \\
\hline GCE/PAPBA-Au NC & $23.4 \mu \mathrm{M}$ & $0.5 \mathrm{mM}-11.0 \mathrm{mM}$ & 34.6 & {$[36]$} \\
\hline $\mathrm{GCE} / \mathrm{TiO}_{2} \mathrm{NW} / \mathrm{PAPBA}-\mathrm{Au} \mathrm{TNC}$ & $9.3 \mu \mathrm{M}$ & $0.5 \mathrm{mM}-11.0 \mathrm{mM}$ & 66.8 & \\
\hline $\mathrm{NiO} / \mathrm{Au} / \mathrm{PANI} / \mathrm{rGO} / \mathrm{GCE}$ & $0.23 \mu \mathrm{M}$ & $90 \mu \mathrm{M}-6000 \mu \mathrm{M}$ & NA & [19] \\
\hline $\mathrm{Au} / \mathrm{PANI} / \mathrm{Pt}$ & $0.5 \mu \mathrm{M}$ & $0.01 \mathrm{mM}-8 \mathrm{mM}$ & 113.6 & This work \\
\hline
\end{tabular}

MWCNTs: Multiwalled carbon nanotubes; GONRs: Graphene oxide nanoribbons; Au-NTAs: gold nanotube arrays; SPCE: screen-printed carbon electrode; $\mathrm{TiO}_{2} \mathrm{NW}$ : titanium dioxide nanowire; PAPBA: poly(3-aminophenyl boronic acid); AuNC: gold nanocomposite; TNC: ternary nanocomposite; $\mathrm{rGO}:$ reduced graphene oxide nanocomposites $(\mathrm{NiO} / \mathrm{Au} / \mathrm{PANI} /) ;{ }^{*} \mathrm{unit}: \mu \mathrm{A} / \mathrm{mA} . \mathrm{cm}^{2}$. 
fere in the oxidation of glucose. Thus, it is required to fabricate a sensor that can show selectivity to glucose exclusively in the presence of many interferents. The level of glucose found in food and human blood is much higher than interfering species. ${ }^{37}$ We studied the selectivity behavior of $\mathrm{Au} / \mathrm{PANI} / \mathrm{Pt}$ sensor in presence of AA, UA, and sucrose by CA technique. In this process, $0.1 \mathrm{mM}$ AA, $0.1 \mathrm{mM}$ UA, $0.1 \mathrm{mM}$ sucrose, and $1 \mathrm{mM}$ glucose were added successively in $0.1 \mathrm{M} \mathrm{NaOH}$ at an interval of $50 \mathrm{~s}$ (applied potential: $+0.067 \mathrm{~V}$ ). It is very clear from Fig. 10a that the current response for glucose is much higher than for other interferents. This validates that the proposed $\mathrm{Au} / \mathrm{PANI} / \mathrm{Pt}$ sensor shows selectivity to glucose.

The stability of a sensor is its performance over a period of time. The stability of our Au/PANI/Pt sensor was studied by recording the current response towards oxidation of $10 \mathrm{mM}$ glucose once in 7 days for a period of 3
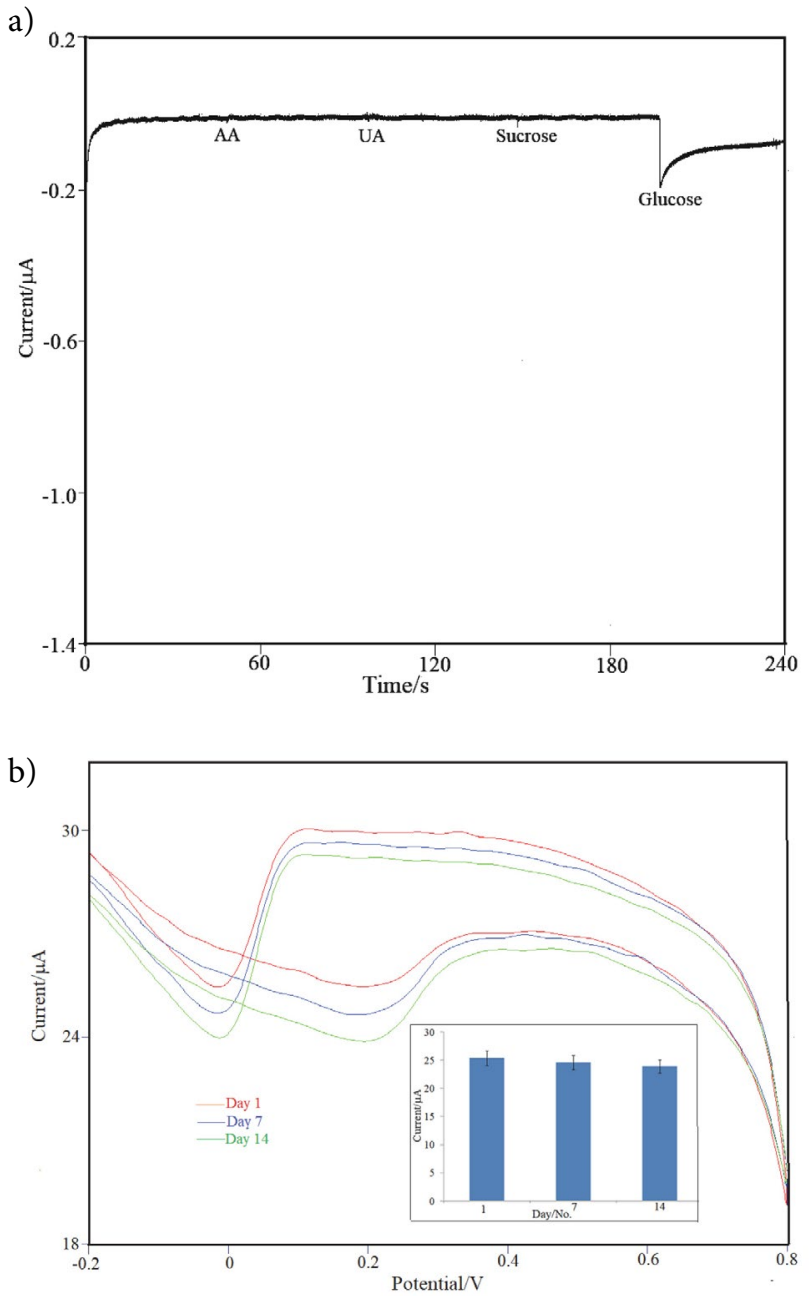

Figure 10. (a) Effect of interfering species on Au/PANI/Pt electrode in presence of $1 \mathrm{mM}$ glucose in $0.1 \mathrm{M} \mathrm{NaOH}$. (b) The current response of Au/PANI/Pt electrode recorded on Day 1, Day 7, and Day 14. Insert shows bar graph plotted for response current obtained over 3 weeks (with SD error bars). weeks. When not in use, the sensor was stored at room temperature. From Fig. 10b, it was calculated that the response current decreases for only $5.9 \%$ of its initial value. Hence, we can confirm that our sensor shows excellent stability.

\subsubsection{Reproducibility \& Repeatability}

Reproducibility is defined as the similarity among current responses from identical electrodes for same analyte. The reproducibility of the Au/PANI/Pt sensor was studied by fabricating five identical Au/PANI/Pt sensors with same procedure. These sensors were used to study the current response against $10 \mathrm{mM}$ glucose in $0.1 \mathrm{M} \mathrm{NaOH}$ and RSD of only $2.97 \%$ was observed (Fig. 11a).

Repeatability is the agreement between the succeeding current responses recorded for the same analyte. The repeatability of the proposed sensor was considered by recording successive fifteen current responses with $10 \mathrm{mM}$ glucose (Fig. 11b). The sensor showed RSD of only $3.92 \%$ for repeated measurements. From these data, we can confirm that our Au/PANI/Pt sensor shows excellent reproducibility and repeatability.

a)

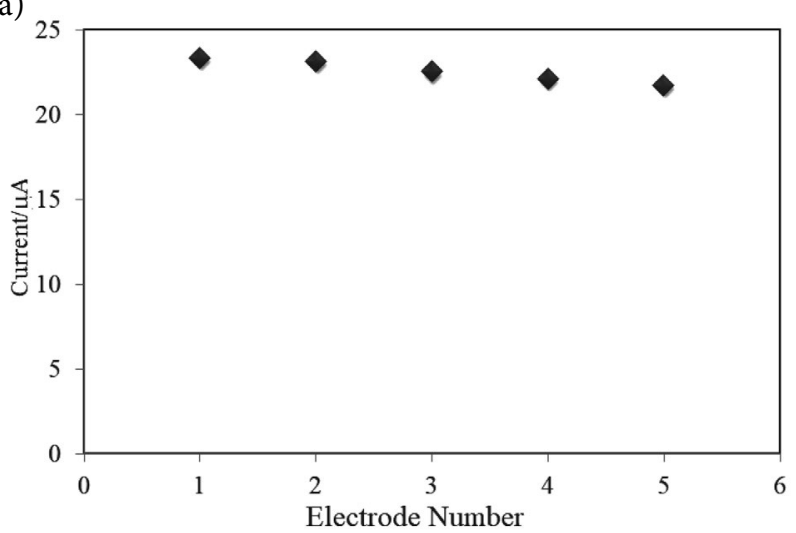

b)

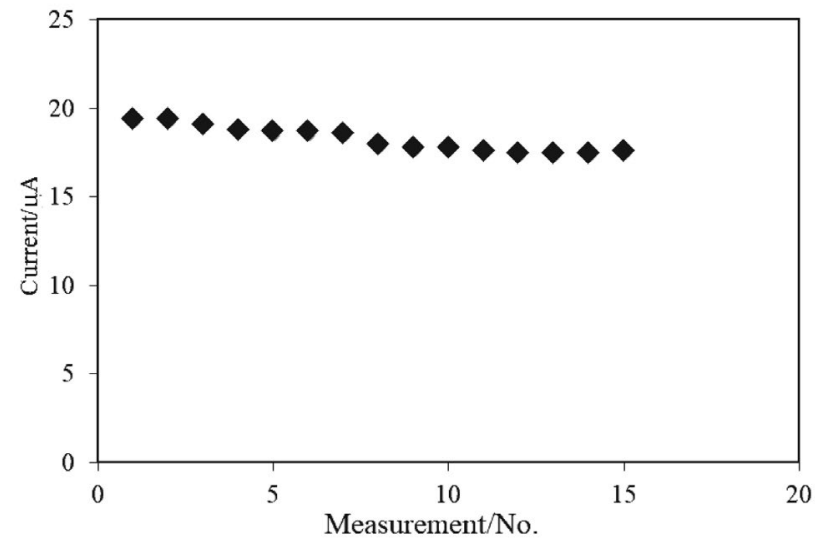

Figure 11. Current response towards $10 \mathrm{mM}$ glucose in $0.1 \mathrm{M}$ $\mathrm{NaOH}$ (a) with five identical Au/PANI/Pt sensors (b) for 15 successive measurements with Au/PANI/Pt electrode. 


\section{Detection of Glucose in Juice With Au/PANI/Pt Sensor}

The as-prepared Au/PANI/Pt sensor was used to detect glucose in boxed juice samples and the results obtained were compared to the commercial glucose meter $\left(\right.$ TRUEtrack $\left.^{\circledR}\right)$. Three different varieties of boxed juices (mango, pineapple, and orange) were taken from local store and each of them was diluted to 1:100 for performing standard addition method. Equal volumes of the diluted juice samples were spiked with different concentrations of glucose viz, $1 \mathrm{mM}, 2 \mathrm{mM}, 3 \mathrm{mM}$, and $4 \mathrm{mM}$ and the
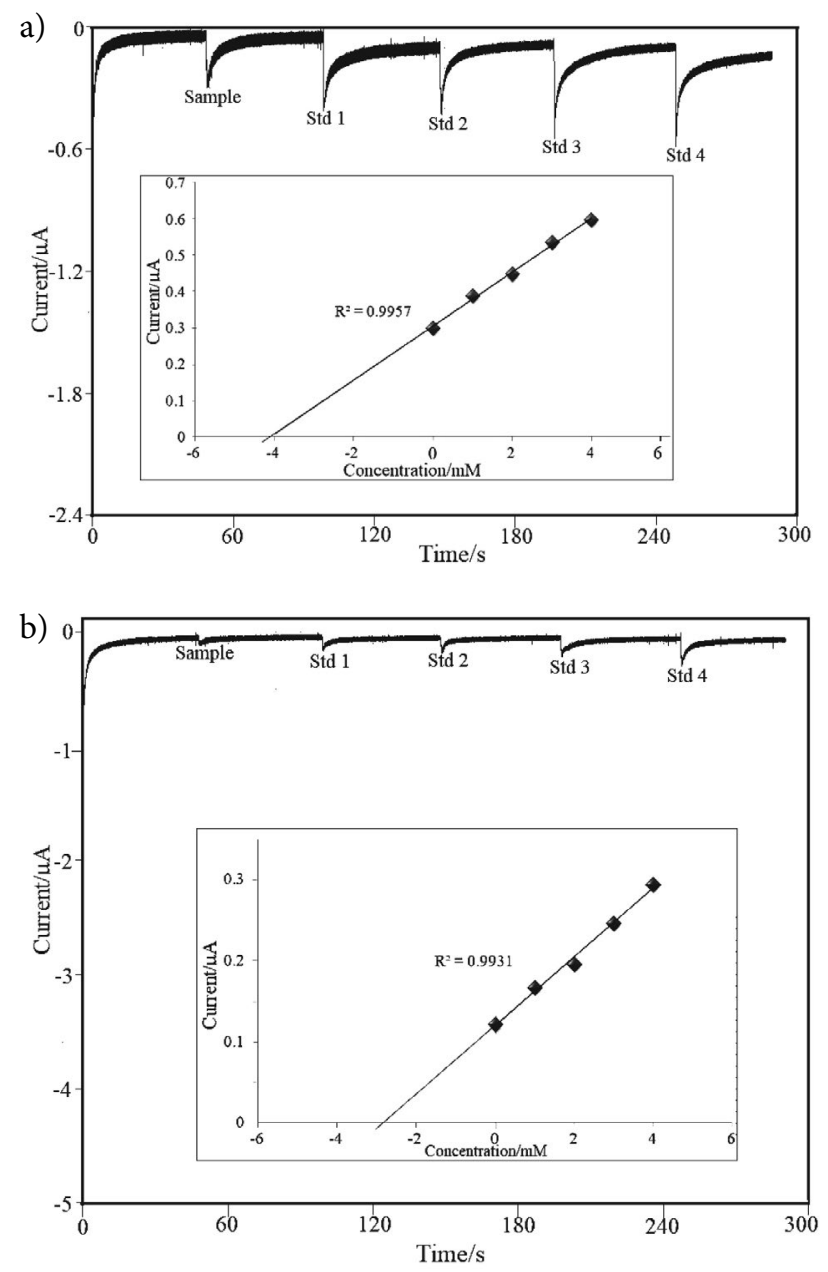

as-prepared solutions were marked as Std 1, Std 2, Std 3, and Std 4 respectively. Figs. 12 a, b and c show the chronoamperometric response of $\mathrm{Au} / \mathrm{PANI} / \mathrm{Pt}$ electrode when equal volumes of each of the samples were added sequentially at an interval of $50 \mathrm{~s}$ at an applied potential $+0.067 \mathrm{~V}$. The concentration of the glucose was determined from extrapolating the standard addition plot between the response current and glucose concentration in standard solutions. A linear regression coefficient $\left(\mathrm{R}^{2} \sim 0.99\right)$ is obtained for each of the samples. Table 2 indicates that the concentrations of the glucose obtained from our $\mathrm{Au} /$ $\mathrm{PANI} / \mathrm{Pt}$ sensor are in good agreement with reference glucose meter. These results confirm that our sensor is reliable for accurate measurements of glucose in practical use.

\section{Conclusions}

In summary, we fabricated highly sensitive non-enzymatic glucose sensor with the deposition of Au particles on PANI matrix modified Pt electrode for determination of glucose. The Au particles were deposited from $\mathrm{KAuCl}_{4}$ solution based on section of optimum growth conditions for better performance of the sensor. The Au particles provided active surface area for an increased electrocatalytic activity. The sensor showed high sensitivity of 113.6

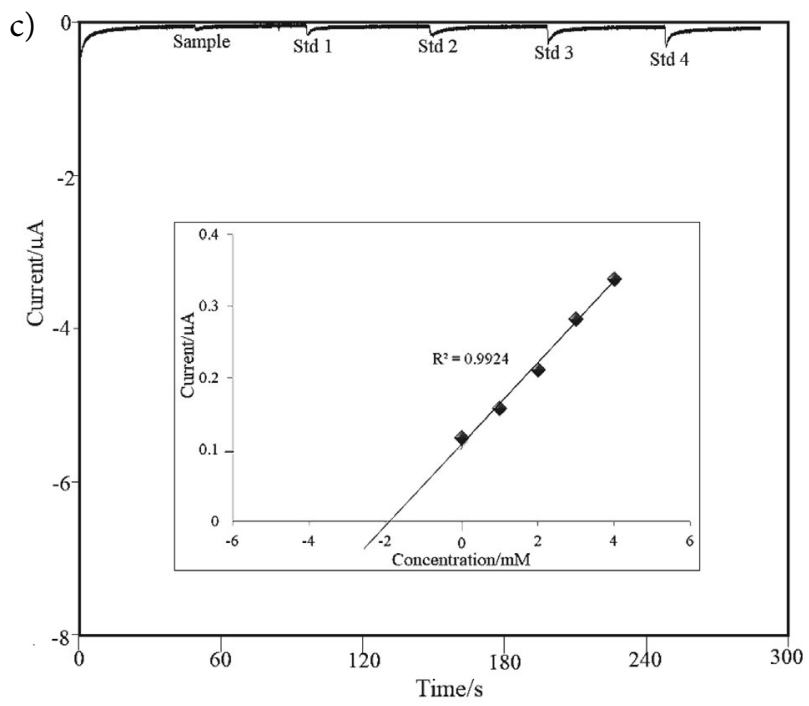

Figure 12. Chronoamperometric response of $\mathrm{Au} / \mathrm{PANI} / \mathrm{Pt}$ electrode in determination of glucose in (a) mango juice, (b) pineapple juice, and (c) orange juice. Std1:1 mM, Std2: $2 \mathrm{mM}$, Std3: $3 \mathrm{mM}$, Std4: $4 \mathrm{mM}$ glucose. Insert shows the respective standard addition graph.

Table 2. Concentration of glucose recorded in various boxed juice samples

\begin{tabular}{lccc}
\hline $\begin{array}{l}\text { Juice } \\
\text { Sample }\end{array}$ & $\begin{array}{l}\text { Glucose determined } \\
\text { by Au/PANI/Pt sensor } \\
(\mathbf{m m o l} / \mathbf{L})\end{array}$ & $\begin{array}{l}\text { Glucose shown by Glucose } \\
\text { meter }(\mathbf{m m o l} / \mathbf{L})\end{array}$ & Bias \\
\hline Mango & 20.4 & 19.5 & 0.9 \\
Pineapple & 14.0 & 15.0 & -1.0 \\
Orange & 8.7 & 8.8 & -0.1 \\
\hline
\end{tabular}


$\mu \mathrm{A} \mathrm{mM} \mathrm{m}^{-1} \mathrm{~cm}^{-2}$ with low detection limits of $0.5 \mu \mathrm{M}$. Also, the response time of the sensor was much less than $5 \mathrm{~s}$. Apart from these performance parameters, the proposed $\mathrm{Au} / \mathrm{PANI} / \mathrm{Pt}$ sensor has shown excellent stability, reproducibility and repeatability. The sensor was able to show selectivity to only glucose in presence of many other interfering species (AA, UA, and sucrose). The applicability of the sensor was verified with detection of glucose in a variety of boxed juice samples and these results were comparable to commercial glucose meter. The excellent performance parameters of our sensor verify that it is a promising non-enzymatic glucose sensor for routine examination of glucose.

\section{Acknowledgements}

We gratefully acknowledge financial support from the University of Wisconsin Oshkosh Faculty Development Program. We would like to thank Dr. Todd Kostman of Biology Department of UW Oshkosh for conducting SEM work. Also, we are thankful to Dean, Faculty of Engineering and Technology, Manav Rachna International Institute of Research \& Studies (formerly as MRIU), Faridabad, for his kind support.

\section{References}

1. G. Wang, X. He, L. Wang, A. Gu, Y. Huang, B. Fang, B. Geng and X. Zhang. Microchim. Acta 2013, 180, 161-186.

DOI:10.1007/s00604-012-0923-1

2. Z. Wang, H. Lei and L. Feng, Spectrochim. Acta A 2013, 114, 293-297. DOI:10.1016/j.saa.2013.05.089

3. J. Anojčić, V. Guzsvány, O. Vajdle, D. Madarász, A. Rónavári, Z Kónya, K. Kalcher, Sens. Actuators B Chem. 2016, 233, 8389. DOI:10.1016/j.snb.2016.04.005

4. J. Mohapatra, B. Ananthoju, V. Nair, A. Mitra, D. Bahadur, N. V. Medhekar, M. Aslam, Appl. Surf. Sci. 2018, 442, 332-341. DOI:10.1016/j.apsusc.2018.02.124

5. S. A. Rothwell, S. J. Killoran and R. D. O'Neill, Sensors 2010, 10, 6439-6462. DOI:10.3390/s100706439

6. K. Tian, M. Prestgard and A. Tiwari, Mater. Sci. Eng. C 2014, 41, 100-118. DOI:10.1016/j.msec.2014.04.013

7. Q. Wang, X. Cui, J. Chen, X. Zheng, C. Liu, T. Xue, H. Wang, Z. Jin, L. Qiao and W. Zheng, RSC Adv. 2012, 2, 6245-6249.

8. H. Çiftçi, E. Alver, F. Çelik, A. Ü. Metin and U. Tamer, Microchim. Acta. 2016, 183, 1479-1486.

DOI:10.1007/s00604-016-1782-y

9. S. Ameen, M. S. Akhtar and H. S. Shin, Appl. Catal. A 2016, 517, 21-29. DOI:10.1016/j.apcata.2016.02.023

10. X. Zhuang, C. Tian, F. Luan, X. Wu and L. Chen RSC Adv. 2016, 6,92541-92546.

11. L. Liu, Y. Chen, H. Lv, G. Wang, X. Hu and C. Wang, J. Solid State Electrochem. 2015, 19, 731-738.

DOI:10.1007/s10008-014-2659-9
12. M. A. Hocevar, G. Fabregat, E. Armelinb, C. A. Ferreira and C. Alemán, Eur. Polym. J. 2016, 79,132-139.

DOI:10.1016/j.eurpolymj.2016.04.032

13. M. Mazloum-Ardakani, E. Amin-Sadrabadi and A. Khoshroo, J. Electroanal. Chem. 2016, 775,116-120.

DOI:10.1016/j.jelechem.2016.05.044

14. O. G. Sahin, H. Gulce and A. Gulce, J. Electroanal. Chem. 2013, 690, 1-7. DOI:10.1016/j.jelechem.2012.11.021

15. J. Yang, M. Cho, C. Pang and Y. Lee, Sens. Actuators B Chem. 2015, 211, 93-101. DOI:10.1016/j.snb.2015.01.045

16. A. G. Mac Diarmid and A. J. Epstein, Synth. Met. 1995, 69, 85-92. DOI:10.1016/0379-6779(94)02374-8

17. C. Dhand, N. Dwivedi, S. Mishra, P.R. Solanki, V. Mayandi, R. W. Beuerman, S. Ramakrishna, R. Lakshminarayanan and B.D. Malhotra, Nanobiosensors in Disease Diagnosis, 2015, 4, 25-46.

18. G. H. Wu, X. H. Song, Y. F. Wu, X. M. Chen, F. Luo and X. Chen, Talanta 2013, 105, 379-385.

DOI:10.1016/j.talanta.2012.10.066

19. Kh. Ghanbari and Z. Babaei, Anal. Biochem. 2016, 498, $37-$ 46. DOI:10.1016/j.ab.2016.01.006

20. A. J. Wang, J. J. Feng, Y. F. Li, J. L. Xi and W. J. Dong, Microchim. Acta 2010, 171,431-436.

DOI:10.1007/s00604-010-0452-8

21. D. W. Hatchett, M. Josowicz and J. Janata, J. Phys. Chem. B 1999,103, 10992-10998. DOI:10.1021/jp991110z

22. A. Saheb, J. A. Smith, M. Josowicz, J. Janata, D.R. Baer and M. H. Engelhard, J. Electroanal. Chem. 2008, 621, 238-244. DOI:10.1016/j.jelechem.2007.11.025

23. J. M. Kinyanjui, J. Hanks, D.W. Hatchett, A. Smith and M. Josowicz, J. Electrochem. Soc. 2004, 151, D113-D120. DOI:10.1149/1.1808593

24. T. Kangkamano, A. Numnuam, W. Limbut, P. Kanatharana and P. Thavarungku, Sens. Actuators B Chem. 2017, 246, 854863. DOI:10.1016/j.snb.2017.02.105

25. V. E. Coyle, A. E. Kandjani, Y. M. Sabri and S. K. Bhargava, Electroanalysis 2017, 29, 294 - 304.

DOI:10.1002/elan.201600138

26. F. Matsumoto, M. Harada, N. Koura and S. Uesugi, Electrochem. Commun. 2003, 5, 42-46. DOI:10.1016/S1388-2481(02)00529-5

27. Md. M. Hasan, Md. E. Hossain, M. A. Mamun and M.Q. Ehsan, J. Saudi Chem. Soc. 2012, 16,145-151.

28. S. Chaiyo, E. Mehmeti, W. Siangproh, T. L. Hoang, H. P. Nguyen, O. Chailapakul and K. Kalcher, Biosens. Bioelectron. 2018, 102, 113-120. DOI:10.1016/j.bios.2017.11.015

29. N. S. Ismail, Q. H. Le, H. Yoshikawa, M. Saito and E. Tamiya, Electrochimica. Acta 2014, 146, 98-105.

DOI:10.1016/j.electacta.2014.08.123

30. G. Chang, H. Shu, K. Ji, M. Oyama, X. Liu and Y. He, Appl. Surf. Sci. 2014, 288, 524- 529.

DOI:10.1016/j.apsusc.2013.10.064

31. C. Shen, J. Su, X. Li, J. Luo and M. Yang, Sens. Actuators B Chem. 2015, 209, 695-700. DOI:10.1016/j.snb.2014.12.044

32. A. J. S. Ahammad, A. Al Mamun, T. Akter, M. A. Mamun, S. Faraezi and F. Z. Monira, J. Solid State Electrochem. 2016, 20, 1933-1939. DOI:10.1007/s10008-016-3199-2 
33. A. N. Kawde, M. A. Aziz, M. El-Zohri, N. Baig and N. Odewunmi, Electroanalysis, 2017, 29, 1214-1221.

DOI:10.1002/elan.201600709

34. T. Tian, J. Dong and J. Xu, Microchim. Acta 2016, 183,19251932. DOI:10.1007/s00604-016-1835-2
35. N. X. Viet and Y. Takamura, Journal of Science: Natural Sciences and Technology 2016, 32, 83-89.

36. N. Muthuchamy, A. Gopalan and K. P. Lee, RSC Adv. 2018, 8 , 2138-2147.

37. K. M. El Khatib and R. M. Abdel Hameed, Biosens. Bioelectron. 2011, 26, 3542-3548. DOI:10.1016/j.bios.2011.01.042

\section{Povzetek}

Razvili smo visoko občutljivi amperometrični neencimatski senzor za glukozo z modifikacijo Pt elektrode z elektrodepozicijo Au delcev na polianilinski film. Depozicija Au delcev je potekala pod optimalnimi rastnimi pogoji, s čimer smo dobili maksimalno disperzijo na polimernem filmu in pridobili visoko občutljiv senzor za glukozo. Karakterizacijo elektrode in določitev analitskih parametrov smo naredili s kronoamperometrijo in ciklično voltametrijo. Senzor je pokazal široko linearno območje od 0,01 - $8 \mathrm{mM}$ ter hiter čas odgovora v manj kot $5 \mathrm{~s}$, hkrati z visoko občutljivostjo 113,6 $\mu \mathrm{A} \mathrm{mM} \mathrm{m}^{-1} \mathrm{~cm}^{-2}$ in nizko mejo zaznave $0,5 \mu \mathrm{M}$. Senzor je pokazal tudi visoko stabilnost, obnovljivost in ponovljivost. Nadalje je senzor pokazal visoko selektivnost za glukozo v prisotnosti interferentov, kot so saharoza, sečna kislina in askorbinska kislina. Praktično uporabnost predlaganega senzorja smo potrdili z uspešno določitvijo glukoze v različnih vzorcih soka in ti rezultati so bili primerljivi z rezultati komercialnega glukozometra. Naš senzor je torej obetaven neencimatski senzor za rutinsko določanje glukoze. 